№ 30 (2021) C. 92-106

National Academy of Fine Arts and Architecture

Collection of Scholarly Works «Ukrainian Academy of Art»

ISSN 2411-3034

Website: http://naoma-science.kiev.ua/

УДК 7.02:62-242.3

ORCID ID 0000-0003-1852-186X

DOI: https://doi.org/10.33838/naoma.30.2021.92-106

\title{
Наталія Ревенок
}

кандидат мистецтвознавства, ст. викладач кафедри техніки та реставрації творів мистецтва Національної академії образотворчого мистецтва і архітектури (м. Київ)

renata_ishtar@ukr.net

\section{НАУКОВА РЕСТАВРАЦІЯ ТВОРІВ ДЕКОРАТИВНО-УЖИТКОВОГО МИСТЕЦТВА В СИСТЕМІ ВИЩОЇ ХУДОЖНЬОЇ ОСВІТИ}

\begin{abstract}
Анотація. Статтю присвячено питанням наукової реставрації творів декоративно-ужиткового мистецтва в системі вищої художньої освіти. Підготовка фахівців за цією спеціальністю проводиться у Національній академії образотворчого мистецтва і архітектури. Визначено процеси формування та вдосконалення досвіду художника-реставратора для збереження пам'яток історії та культури. Окреслено сучасну наукову методологію реставраційного втручання, зокрема, в галузі реставрації творів декоративно-ужиткового мистецтва. Узагальнено відомості стосовно дослідження, документування стану збереженості та етапів реставрації; визначено послідовність та характер реставраційних процесів на творах декоративно-ужиткового мистецтва з металу, кераміки, тканин.
\end{abstract}

Ключові слова: реставрація, консервація, дослідження, метал, кераміка, органічні матеріали, тканини.

\section{SCIENTIFIC RESTORATION OF WORKS OF DECORATIVE AND APPLIED ART IN THE SYSTEM OF HIGHER ART EDUCATION}

\section{Natalia Revenok}

Abstract. The article is devoted to the issues of scientific restoration of works of decorative and applied art in the system of art education at the National Academy of Fine Arts and Architecture. The processes of formation and improvement of the experience of the artist-restorer for the preservation of historical and cultural monuments are defined. The importance of solving the cultural and professional development of the future artist-restorer in the field of restoration of works of decorative and applied art is emphasized. The topic studied by the author raises a number of issues of the methodology of studying works of decorative and applied arts in the research work of future artists-restorers. The purpose of the study is to develop and substantiate basic theoretical knowledge in the field of research, restoration, conservation and storage of works of decorative and applied arts from metal, ceramics and organic materials. Training of restoration specialists is carried out in various educational and scientific institutions of Ukraine. At the present stage of development of scientific restoration, this industry needs innovative approaches and updating of old methods. Thus, at the National Academy of Fine Arts and Architecture you can get a specialty artist-restorer of monumental painting, artist-restorer of sculptures and decorative arts from metal, ceramics, organic materials (fabrics, leather and bone). Restoration occupies the most important place in museum work and combines a set of knowledge and skills that provide storage of works of art made of metal, ceramics and organic materials. Disciplines on the restoration of sculpture and works of decorative and applied art are part of the training of specialists in the specialty «Restoration of works of art» within the acquisition of practical skills in research, restoration, conservation and storage. Training of future 
artists-restorers in the system of higher professional education taking into account modern requirements of conservation and restoration is based on such principles as scientific, connection of theory with practice should be carried out on authentic monuments - museum exhibits that promotes formation of professional competences, acquisition of professional experience, responsible attitude to historical and cultural monuments. The obtained results deepen the idea of research methods, restoration and conservation of works of decorative and applied arts from metal, ceramics and organic materials. Theoretical provisions are important at the problem-theoretical level, because the training of restorers requires a strong scientific and methodological base.

Keywords: restoration, conservation, research, metal, ceramics, organic materials, textiles.

Постановка проблеми. Підготовка фахівцівреставраторів здійснюється в різних навчальних і наукових установах України. На сучасному етапі розвитку наукової реставрації ця галузь потребує інноваційних підходів та оновлення старих методик. У Національній академії образотворчого мистецтва і архітектури можна отримати дві спеціальності - художника-реставратора станкового і монументального живопису й художника-реставратора творів скульптури та декоративно-ужиткового мистецтва. Це - єдиний в Україні вищий навчальний заклад, де можна навчитись основам наукової реставрації творів декоративно-ужиткового мистецтва з металу, кераміки, органічних матеріалів (тканини, шкіри, кістки, дерева). В інших навчальних закладах ведеться підготовка за спеціальністю реставратора творів монументального й станкового (олійного та темперного) живопису. Це Харківська державна академія дизайну і мистецтв, Львівська національна академія мистецтв, Львівський державний коледж декоративного і ужиткового мистецтва ім. І. Труша, Кам'янець-Подільський державний університет імені І. Огієнка.

Підготовку реставраторів різних спеціальностей здійснюють також наукові установи в рамках системи стажувань. Атестація фахівцівреставраторів здійснюється Міністерством культури та інформаційної політики України. Існують різні кваліфікаційні характеристики художників-реставраторів залежно від напрямку реставраційної діяльності. Виокремлюють напрямки в реставрації живопису, металу, кераміки, скла, тканини, шкіри, кістки, скульптури, паперу, дерева, меблів тощо. В рамках напрямків вирізняються вужчі спеціалізації. Наприклад, серед художників-реставраторів живопису є реставратори монументального живопису та мозаїки у пам'ятках архітектури, станкового олійного та темперного живопису. Серед художників-реставраторів скульптури - реставратори поліхромної дерев'яної скульптури та декоративного різьблення, кам'яної та гіпсової архітектурно-декоративної скульптури (в пам'ятках архітектури). Серед художниківреставраторів декоративно-ужиткового мистецтва - творів з металу, кераміки і скла, 3 тканини, шкіри, кістки та рога, меблів та етнографічних пам'яток з дерева.

Рівні професійної майстерності визначаються кваліфікаційними категоріями: III, II, I та вищою категорією. Діяльність з реставрації та консервації пам'яток регламентується низкою міжнародних і національних нормативних документів. Крім Венеційської хартії найважливішим міжнародним документом є Конвенція про охорону всесвітньої культурної і природної спадщини ЮНЕСКО, прийнята в 1972 році. Комітет Всесвітньої спадщини періодично проводить сесії, на яких визначаються об'єкти програми, зокрема, об'єкти культурної спадщини, які мають особливу культурну та історичну цінність.

В Україні діяльність про охорону та реставрацію визначається законом Верховної Ради від 16.12.2004 № 2245-IV «Про охорону культурної спадщини», законом від 29.06.1995 № 25 «Про музеї та музейну справу», постановою Кабінету Міністрів України від 20 липня 2000 р. № 1147 «Про Музейний фонд України», «Інструкцією 3 організації обліку музейних предметів», затвердженою наказом Міністерства культури України № 580 від 21.07.2016 р. та іншими нормативними документами.

Актуальність дослідження визначається необхідністю поглибленого вивчення питань наукової реставрації творів декоративно-ужиткового мистецтва в системі художньої освіти під час формування та вдосконалення досвіду художника-реставратора для збереження пам'яток історії та культури. 
Реставрації належить найважливіше місце в музейній справі, вона поєднує комплекс знань і умінь, які забезпечують зберігання творів мистецтва з металу, кераміки, органічних матеріалів.

Дисципліни з реставрації скульптури та творів декоративно-ужиткового мистецтва є складовою частиною підготовки фахівців спеціальності «Реставрація творів мистецтва» у межах набуття ними практичних навичок з дослідження, консервації-реставрації та зберігання творів мистецтва. Тому дана стаття може стати основою методичної розробки для студентів НАОМА, які опановують освітньо-професійну (рівня бакалавр) та освітньо-наукову (рівня магістр) програми «Реставрація творів скульптури та декоративно-ужиткового мистецтва» на кафедрі техніки та реставрації творів мистецтва НАOMA.

Зв'язок авторського доробку з важливими науковими та практичними завданнями. Дослідження виконане відповідно до плану науководослідної роботи кафедри техніки та реставрації творів мистецтва Національної академії образотворчого мистецтва і архітектури на 2020-2021 навчальний рік.

Аналіз останніх досліджень та публікацій. Проблеми наукової реставрації творів мистецтва хвилюють майже всіх фахівців, які працюють у музеях, артгалереях тощо.

Відображення цієї проблеми знаходимо в дослідженні В. Зайцевої про роль наукової реставрації творів образотворчого мистецтва. Авторка розглядає проблеми сучасної реставрації як складного комплексу науково-теоретичних і практичних знань, що є інструментом не тільки збереження пам'яток, але й глибокого вивчення їх.

Багатопланові зміни в реставраційній діяльності на сучасному рівні характеризують не тільки зростаючий у ній кількісний процес, але й вказують на практичний перегляд колишніх реставраційних принципів та оцінок, визначають якість і межі консерваційно-реставраційного втручання, можливість зберегти їх для нащадків (Зайцева 26-7). Тобто актуалізується необхідність розгляду всіх складних процесів, що виникають, та їхнє наукове обгрунтування.
Дослідження з реставрації творів з металу представлені у підручнику професора О. Мінжуліна «Реставрація творів з металу», тканини - у підручниках О. Мінжуліна, Т. Мінжуліної, І. Чорнокапської «Реставрація тканин» та Т. Мінжуліної «Дослідження й реставрація музейного текстилю» (Мінжулін, Мінжуліна, Чорнокапська).

Публікації з реставрації творів кераміки в Україні представлені переважно невеликими статтями. У них реставраційні питання та методичні розробки висвітлено здебільшого тезами. Зокрема, на науково-практичних конференціях Національного науково-дослідного реставраційного центру України реставраторами кераміки С. Єфановою та Т. Коваленко (Коваленко 61-62) не в повному обсязі відображено специфіку наукової реставрації.

Питання проблем реставраційної освіти в Україні висвітлено у статті завідувача кафедри техніки та реставрації творів мистецтва Т. Тимченко (268-272).

Зазначення невирішених раніше частин загальної проблеми, яким присвячується стаття. Досліджувана автором тема порушує низку питань, що стосуються методики вивчення творів декоративно-ужиткового мистецтва у науководослідній роботі майбутніх художників-реставраторів.

Новизна наукового дослідження. У статті вперше теоретично узагальнено прийоми проведення дореставраційних досліджень пам'яток 3 металу, кераміки, органічних матеріалів (зокрема, тканин); основні методологічні засади їхньої реставрації; окреслено найтиповіші процеси консервації-реставрації; висвітлено необхідні заходи для підтримки стабільності творів у музейних умовах.

Метою дослідження $є$ розробка й обгрунтування базових теоретичних знань у галузі дослідження, консервації-реставрації та зберігання творів декоративно-ужиткового мистецтва з металу, кераміки, органічних матеріалів (зокрема, тканин).

Методологічне значення. Отримані результати поглиблюють уявлення про методики досліджень, консервації та реставрації творів декоративно-ужиткового мистецтва з металу, кераміки, органічних матеріалів (зокрема, 
тканин) і можуть бути використані як методичні рекомендації для процесу навчання студентів, а також для фахівців-реставраторів і музейних співробітників, до сфери інтересів яких входять твори декоративно-ужиткового мистецтва.

Виклад основного матеріалу. Реставраційні заходи передбачають збереження предметів історичної та культурної спадщини - творів образотворчого, декоративно-прикладного мистецтва і архітектури.

Реставрація (як узагальнюючий термін) це комплекс заходів, спрямованих на запобігання подальших руйнувань пам'яток та досягнення оптимальних умов їхнього тривалого зберігання, забезпечення можливостей подальшого відкриття нових, раніше невідомих властивостей збережених творів.

Консервація - основа можливості тривалого зберігання музейних предметів. Консервація поділяється на превентивну й оперативну. Превентивна консервація спрямована на створення певного режиму зберігання музейних предметів, який припиняє процеси їхнього природного старіння, захищає від зовнішніх впливів, забезпечує стабільний стан в умовах музею. Oneративна консервація забезпечує призупинення руйнівних процесів шляхом безпосереднього втручання у структуру пам'ятки та виконання цілої низки активних заходів (Бобров).

Консервація-реставрація - це складна і надзвичайно відповідальна робота, адже невірно обраний чи недостатньо апробований метод усунення пошкоджень може призвести до втрати предмета. Тому питання про доцільність, можливості, засоби й методи консерваціїреставрації вирішують спеціальні комісії або реставраційні ради. Їхній висновок фіксують у протоколі, а етапи й результати практичної роботи з предметом реставратори відображають у спеціальному документі.

Реставрація зазвичай є незворотним процесом, тому необхідною іiі умовою є ретельне попереднє дослідження предмета істориками, мистецтвознавцями, реставраторами для отримання найкращого кінцевого результату. Слід зазначити, що сучасна консервація і реставрація предметів часто зводиться до забезпечення стабільності матеріалу, без застосування заходів, що кардинально змінюють справжній вигляд предмета. Тільки обережність, невтручання в природу предмета дають змогу зберегти оригінальність пам'ятки. Доповнення втрат на твоpax здійснюється таким чином, щоб доповнення за потреби можна було легко видалити, з використанням матеріалів подібних, але відмінних від авторських.

Процес реставрації передбачає обов'язкове дослідження пам'ятки, фотофіксацію всіх заходів на різних етапах реставраційного втручання, контроль за їхнім виконанням. Всі етапи консервації і реставрації, опис стану предмета до і після реставраційних заходів фіксують у паспорті реставрації.

Найскладнішим і найвідповідальнішим у справі реставрації є прийняття рішення про ступінь реставраційного втручання, яке приймається колегіально.

Згідно з рекомендаціями провідних реставраторів, консервація покращує умови режиму зберігання музейних предметів, вирішує питання їхнього експонування. Консервація - це також комплекс заходів з надання первинної допомоги, зокрема, археологічним предметам, які часто потребують негайної стабілізації, тому необхідні консерваційні роботи виконують під час археологічних розкопок у польових умовах, а лабораторну консервацію - одночасно з проведенням реставраційних заходів.

Основне завдання польової консервації - збереження предмета 3 моменту вилучення його 3 культурного шару до передачі в реставраційну лабораторію, надання йому певної хімічної стійкості і механічної міцності, тобто стабілізація. Лабораторна консервація іноді полягає у встановленні правильного режиму зберігання речей. Забруднення на предметах складаються з грунту, змішаного з жировими нашаруваннями, продуктами корозії, органічними речовинами. Очищення предметів зазвичай поєднується 3 консерваційними та реставраційними заходами і може проводитися навіть у польових умовах. Для цього використовують м'які пензлі, щітки, ножі тощо. Очищення погано збережених предметів або ж окремих їхніх фрагментів здійснює реставратор, з таких речей не можна видаляти продукти корозії, що змішані з грунтом. Першочергового укріплення вимагають крихкі, зруйновані, фрагментовані металеві предмети. 
Зміцнювати їх необхідно розчинами, які легко видалити під час подальших реставраційних робіт, тобто розчини мають бути оборотними.

\section{$\square$ Реставрація творів з металу.}

Музейні предмети з металів являють собою велику категорію, що включає групи речей, виготовлених з різних металів та їхніх сплавів, різних за видами та ступенем руйнування (корозіi).

Корозія (від лат. corrosio - «роз'їдання») це процес самовільного руйнування металів та їхніх сплавів під впливом зовнішнього середовища. За характером, залежно від зовнішніх умов, розрізняють хімічну та електрохімічну, грунтову та атмосферну, суцільну й місцеву, рівномірну і нерівномірну корозії. На швидкість і характер корозійного процесу впливають такі фактори, як хімічний склад металу, технологія виготовлення предмета. Сплави руйнуються швидше за чистий метал, а литі предмети повільніше від кованих, натомість шліфування поверхні предмета робить його стійкішим. Найчастіше зустрічаються предмети, виготовлені 3 міді та мідних сплавів, срібла та сплавів на основі срібла, олова, свинцю, заліза. Коротко охарактеризуємо їх для кращого розуміння властивостей металів.

Midb - це м'який метал червонуватого відтінку. Сплави на основі міді називають бронзою. У стародавніх сплавах зазвичай присутні такі елементи, як олово, миш'як, свинець, цинк та інші. Зовнішній вигляд предмета залежить від складу металу. Так, сплави з домішками цинку та олова за кольором схожі на золото. Корозія міді та мідних сплавів має найскладніший характер. Вона може складатися з декількох шарів, що чергуються солями й оксидами міді: пухких світло- й темно-зеленого кольору (малахіт, атакаміт), твердих - червоно-коричневого (куприт). Іноді предмет може складатися з повністю мінералізованою металу. На предметах, виготовлених з металу якісної обробки, частіше утворюється рівномірний щільний шар корозії темно-зеленого, синьо-зеленого кольорів «благородна патина». Вона захищає предмет від впливу навколишнього середовища. Наприклад, предмети із свинцево-олов'яної бронзи покриваються шаром корозії сірого відтінку. Існує особливий вид корозії міді - «бронзова хвороба». Причинами такої «хвороби» $є$ висока вологість та наявність активних осередків корозії, попадання агресивних речовин на поверхню предмета. У такому випадку розвивається місцева корозія у вигляді плям, заповнених рихлою світло-зеленою речовиною. В результаті утворюються каверни, предмет стає сильно кородованим. Корозійний процес відбувається з великою швидкістю, i, якщо його не зупинити, може призвести до повного руйнування предмета.

Залізо - тугоплавкий метал сірого кольору. Різноманітні способи обробки заліза поступово опановувались на різних історичних етапах. Початковим способом обробки заліза було холодне кування, що згодом змінилось на гаряче. 3 плином часу метал навчилися насичувати вуглецем, отримуючи сталь - міцніший матеріал. Порівняно з іншими металами, залізо має низьку корозійну стійкість, тому археологічний чорний метал найчастіше знаходять в найбільш зруйнованому стані.

Продукти корозії заліза складаються з оксидів і солей. Корозія заліза відбувається дуже активно. Розрізняють декілька видів грунтової корозії заліза: жовто-коричневу порошкоподібну (лимоніт), щільний синій наліт (вівіаніт), світлу рожеву порошкоподібну (сірчанокисла сіль) та інші. Залізо чутливе до змін у навколишньому середовищі, швидкість його корозії значно збільшується після вилучення з культурного шару, тому залізні предмети часто вимагають першочергових заходів після їхнього вилучення з розкопу.

Для стабілізації чорного металу використовують перетворювачі іржі, наприклад, танін. Він також може використовуватися для обробки кольорового металу. Для консервації металевих предметів використовують реставраційні лаки та смоли.

Срібло - це м'який метал, що добре піддається обробці. Срібло також є неактивним металом, тому кородує менше. Завдяки цим властивостям срібло здавна використовували для виготовлення художніх та ювелірних виробів. При їхньому виготовленні застосовують різні прийоми, такі як карбування, гравірування, зернь, філігрань, чернь та інші. Основна властивість археологічного срібла - його крихкість. 
Основним продуктом корозії є рогове срібло шар сірого кольору. Частими знахідками в археології є предмети зі сплавів на основі срібла. Від складу сплаву залежить зовнішній вигляд кородованих предметів. За наявності у срібному сплаві понад $10 \%$ міді корозія подібна до руйнування на бронзових предметах, і предмет виглядає як виготовлений з мідного сплаву.

Олово - це білий пластичний, ковкий метал, який використовували для виготовлення окремих предметів (наприклад, прикрас), а також для отримання бронзи (додаванням у сплави), для покриття мідних і залізних предметів. При температурі, нижчій за $+13^{\circ} \mathrm{C}$, починається руйнування олова, яке змінює колір з білого на сірий, утворюються пухкі сірі плями, які називають «олов'яною чумою».

За ступенем збереження металеві предмети можна розділити на наступні групи:

- 3 хорошим ступенем збереження;

- предмети, що зберегли повну форму, не піддані сильній корозії і спотворенням, вкриті благородною патиною;

- предмети або фрагменти, що зберегли металеве ядро, спотворені товстим шаром корозії;

- предмети повністю мінералізовані, безформні фрагменти. Найбільш активно корозійні процеси відбуваються у другому випадку. Для точного визначення типу і стану предмета застосовують різні методи їхнього дослідження (Шемаханська).

Типологіині ознаки предмета допомагає визначити комплекс знань з історії цивілізацій окремих епох, культур, пам'яток. За допомогою оптико-фізичних, науково-технологічних методів дослідження уточнюють відомості з технології виготовлення та властивостей матеріалів, 3 яких виготовлений предмет.

Для визначення металів та їхнього стану використовують фізичні та хімічні методи. Найпростіші з них може опанувати й музейник; решта потребує спеціального обладнання, фахівців та специфічних умов проведення досліджень. Прикладом можуть слугувати методи визначення металевого ядра.

Металеве ядро в реставрації металу - це збережений під шаром корозії початковий матеріал предмета. Рентгенівське просвічування дає змогу побачити мінералізовані ділянки, на яких метал повністю окислився (Шемаханська). Однак наявність металевого ядра під шаром корозії можна також визначити за допомогою магніту. Активні осередки корозії можна виявити візуально, за допомогою мікроскопа або бінокуляра, а також помістивши предмет у вологу камеру. Для цього на дно посудини наливають воду, предмет розташовують на підставку з отворами, посудину щільно закривають кришкою. Предмет тримають у вологій камері не більше 2-х годин, оскільки це може викликати корозійний процес. За наявності активних осередків корозії на залізному предметі з'являються крапельки води з жовто-коричневими продуктами корозії, на мідному - світло-зелені пухкі плями.

Дослідження стану збереженості предмета здійснюють механічним пошаровим розчищенням невеликої ділянки поверхні, у такий спосіб визначають товщину і щільність продуктів корозії, а також вид металу під корозійним шаром. Наявність металевого ядра можна виявити обережним простукуванням - глухий звук свідчить про повністю мінералізований метал, дзвінкий - про збережене металеве ядро, або ж перевіряючи гнучкою стоматологічною голкою або шабером, а також за питомою вагою.

Здійснені дослідження дають відомості про метал і техніку виготовлення предмета, а також уявлення про обсяг реставраційних робіт та послідовність операцій. Першочергового зміцнення потребують металеві предмети, що розкришуються та руйнуються на шматки. Для укріплення предметів з металу необхідно застосовувати легкорозчинні (оборотні) речовини, що легко видаляються під час подальших реставраційних робіт.

Етапи консерваційної обробки металу передбачають:

- очищення пам'ятки механічним, хімічним, електрохімічним або термічним способами;

- проведення стабілізації предмета шляхом промивання в дистильованій воді, або ж у лужному середовищі, та шляхом обробки органічними розчинниками;

- нанесення захисного покриття шляхом просочення розчинами, розплавленими речовинами, адсорбцією вуглеводневих сполук, комбінованими методами (Мінжулін). 
Умови зберігання предметів з металу відіграють важливу роль у музейній практиці. За недотримання певних правил метал може руйнуватися в порівняно комфортних музейних умовах. Під час зберігання і перевезення металевих предметів часто спостерігаються наступні причини корозії:

- сліди поту й органічних речовин на поверхні металу (потрапляють з відбитками пальців, 3 приклеєних етикеток тощо);

- залишки очищувальних розчинів після поганого промивання під час реставрації;

- хлор і сульфат-іони, що присутні у водопровідній воді, яка застосовується для промивання виробів;

- агресивність навколишнього середовища (повітряна) через підвищену вологість (утворення конденсату при перепаді температури), а також вміст у ньому газів;

- велика кількість пилу.

До корозійного руйнування в музейних умовах схильні практично всі чорні і кольорові метали і їхні сплави, однак зовнішні фактори по-різному впливають на прояв корозії різних груп металів.

Срібло. Відомо, як швидко темніє очищене срібло. Причиною потемніння срібла є в основному сірководень і сірчисті речовини. У приміщенні, де зберігається срібло, не повинні перебувати матеріали, що мають у складі сірку, або ж речовини, схильні до розпаду з виділенням сірководню. Зберегти срібло світлим триваліший час можна за допомогою інгібіторів. Для вітрин, де експонується срібло, рекомендують використовувати натуральний шовк, просочений $10 \%$ розчином оцтовокислого свинцю, 3 додаванням 2\% гліцерину і $1 \%$ аміаку. Після просушування тканину пропрасовують гарячою праскою. Таким шовком вистилають полиці, на яких зберігається срібло в закритих вітринах.

Мідь і мідні сплави. Великою небезпекою для мідних сплавів у замкнутому просторі вітрини або ж на закритих полицях є кислотні випари, які можуть виділятися з дерева при високій вологості. Вологість під час зберігання предметів 3 мідних сплавів не повинна перевищувати $50 \%$. Предмети, що зберігаються на відкритих полицях, мають бути накриті тонким матеріалом, скажімо, маркізетом або туаллю. Пил з поверхні предмета видаляють тільки м'якою щіткою, але не ганчіркою.

Під час зберігання і транспортування виробів з міді та ï сплавів можна застосовувати інгібітор бензотриазол, розчином якого у концентрації 20 г/л просочують пакувальний папір. Упаковка повинна бути герметичною, оскільки інгібітор швидко випаровується. Крафт-папір зберігає інгібітор до 15 місяців, а інгібітований папір за подальшої упаковки в поліетиленову плівку - до 24 місяців.

Свинець. Свинець руйнується парами органічних кислот. Руйнівну дію на нього справляють людський піт і випари оцтової кислоти, що виділяються з погано просушеної деревини; свинцеві предмети не можна зберігати в дубових ящиках.

Олово. Головною небезпекою для олова є знижена температура, при якій починається руйнування - так звана олов'яна чума. Предмети з олова завжди мають зберігатися за кімнатної температури. «Хворі» предмети повинні ізолюватися від «здорових».

Чорні метали. Залізо, як жоден інший метал, чутливе до підвищеної вологості. Якщо для нормального зберігання музейних предметів 3 чорних металів допустимою є $50 \%$ вологість, то для засолених археологічних залізних предметів необхідно підтримувати $20 \%$ вологість, яка може бути досягнута тільки за допомогою осушувачів повітря. Для підтримки постійно низької вологості можна використовувати силікагель. Силікагель - це висушений гель двоокису кремнію у вигляді твердих крихких напівпрозорих гранул, які мають розгалужену капілярну структуру, здатну поглинати значну кількість води. Силікагель може підтримувати постійну відносну вологість повітря навіть за різких перепадів температури, що дуже важливо під час тривалого зберігання предметів. Силікагель потрібно просушувати кожні 6-12 місяців. Якщо експонати зберігають у поліетилені, то рекомендується до пакета розміром $20 \times 30$ см класти 5-6 чайних ложок силікагелю, який насипають до капронового мішечка. Кількість вологи, що поглинається силікагелем (за $50 \%$ відносної вологості) становить 25-30\% від його об'єму.

Особливі проблеми виникають під час транспортування експонатів з металів. Навко- 
лишньому середовищу за таких обставин повинно приділятися стільки ж уваги, скільки й під час зберігання у стаціонарних умовах.

\section{$\square$ Реставрація творів кераміки.}

Реставрація музейних пам'яток 3 кераміки починається з візуальних досліджень і супроводжується описом характерних рис пам'ятки та їі пошкоджень, фотофіксацією до реставрації, у процесі та після реставрації.

Опис має бути виконаний якомога повніше i точно. Загальний опис керамічного виробу починається з визначення матеріалу, з якого він виготовлений; його призначення, форми, живописного та ліпного декору, якщо він $є$.

Ретельний опис усіх пошкоджень пам'ятки $\epsilon$ першоосновою для формулювання завдань реставраційних дій. Пошкодження на керамічних виробах умовно можна розділити на два види: ті, що виникли через технологічні порушення в процесі виготовлення, і пошкодження, отримані за час побутування предмета. Від правильного опису, визначення ступеня збереженості залежить не тільки точне осмислення реставраційних заходів, але й подальша робота реставраторів, а після завершення реставраційних робіт - істориків та мистецтвознавців.

Технологічні пошкодження - до них належать деформації і тріщини черепка, отримані в результаті неякісного збирання відформованих у роздільних формах частин виробу; крихкість, розшарування та руйнування черепка в результаті недостатнього випалу; відшаровування ангобу та глазурі в результаті невідповідності коефіцієнтів розширення керамічної маси і покриття шару ангобів або глазурі, а також поганий зв’язок між черепком і покриттям, - ця група ушкоджень може вплинути на стан збереження пам'ятки. У даному випадку реставраційне втручання є необхідним. До технологічних пошкоджень також належить цек (сітка тріщин на поверхні глазурі); міхури або різного виду здуття на поверхні глазурі; перепал або вигоряння надглазурної фарби, позолоти, іноді до повного знебарвлення; мушки (найдрібніші темні плями на поверхні виробу). Подібні пошкодження знижують якість і художню цінність пам'ятки, але не загрожують ії існуванню або стану збереженості.

\section{Пошкоджсеня, отримані в процесі побутуван-}

$\boldsymbol{\mu я , ~ є ~ б е з п о с е р е д н ь о ю ~ п р и ч и н о ю ~ д л я ~ в и к о н а н н я ~}$ реставраційних дій на пам'ятці. Це - механічні пошкодження, пов'язані з втратою цілісності експоната, до яких відноситься бій - коли пам'ятка розбита на фрагменти; втрати - повна втрата, відсутність окремих деталей або частин виробу; відколи - невеликі втрати поверхневого шару черепка і глазурі; тріщини - поверхневі і наскрізні; подряпини на поверхні черепка або глазурі.

Пошкодження внаслідок непрофесійних реставраційних втручань. Внаслідок недбалості реставраторів на поверхні предметів залишаються фарбові та гіпсові забруднення, нальоти воску, пластилін, плями клею. Іноді виникають деформації і відставання ділянок реставраційних доповнень втрат черепка з причини схильності деяких матеріалів до деформації. Можуть спостерігатись розтріскування і лущення тонувань, потемніння і прожухання живописного шару як наслідок деструкції сполучників покривних лаків, з причини застосування олійних фарб замість акварелі. Вони також є причиною початку процесу руйнування, проникаючи в пори черепка або під розтріскану глазур.

За правилами ведення реставраційного паспорта, необхідно описувати пошкодження у тому порядку, в якому передбачається проведення реставраційних процесів. 3 цього випливає, що спочатку описують пошкодження, викликані забрудненням поверхні, що мають найрізноманітніше походження. Забруднення бувають нестійкі та стійкі.

Забруднення від впливу навколишнього середовища. Пил, що знаходиться у повітрі, взаємодіючи з атмосферною вологою, осідає на керамічних предметах, ущільнюється на поверхні пам'ятки, особливо в заглибленнях та рельєфах. Це не тільки спотворює пам'ятку, але й може викликати, в міру накопичення бруду, процеси руйнування поверхні черепка або декоративного покриття. Особливо від цього виду забруднення страждають археологічні пам'ятки, неглазуровані вироби, оскільки пил разом з вологою проникає в пори черепка. В описі такий вид забруднень має термін «щільні пилові забруднення».

До стійких забруднень належать: жирові, що зустрічаються на поверхні виробів у вигляді 
плям, залишків їжі; сліди від іржі, сажі, кіптяви, а також згадані вище наслідки непрофесійних реставрацій.

Подібні види забруднень притаманні в основному так званій новій кераміці. Однак вироби (скажімо, археологічна кераміка), що зазнають різних впливів агресивного середовища, мають ще й такі види забруднень та руйнації, як засолення, іризацію, мікробіологічні пошкодження.

Засолення - вихід на поверхню кристалічних утворень у вигляді білуватого нальоту або лусочок, що з'являються внаслідок різких коливань режиму температур і вологи, агресивного впливу грунту, світлоповітряного середовища.

Іризація на лужній і лужноземельній глазурі з'являється внаслідок підвищеної вологості середовища, що виявляється в помутнінні, втраті блиску глазурованої поверхні, утворенні плівки з ефектом райдужної мінливості, а потім і лущенні глазурі та перетворенні їі на крихкий білуватий порошок.

Мікробіологічні пошкодження виникають внаслідок розвитку на поверхні кераміки грибкової колонії. Пил, частинки органічних речовин, грунтові забруднення - все це створює при різких коливаннях температурно-вологісного режиму умови для розвитку грибкової корозії. Мікроорганізми в процесі життєдіяльності виділяють продукти обміну - органічні кислоти, забарвлені речовини, які є фактором хімічного руйнування поверхонь керамічних виробів, а також псують зовнішній вигляд, утворюючи темні плями різного забарвлення. Забруднення можуть спостерігатися на поверхні виробу, на поверхні зламу, а також на швах фрагментів.

Способи видалення забруднень бувають різні. Під час проведення такої операції треба враховувати два фактори - ефективність видалення забруднень і вплив видаленої речовини на саму кераміку. Видалення забруднень виконують механічним способом, хімічним та комбінованим. Перед виконанням видалення забруднень необхідно правильно підібрати методи і розчинники. В іншому разі керамічному виробу буде завдано непоправної шкоди.

Механічний спосіб - це видалення забруднень щітками різної жорсткості, зскрібання або відшарування скальпелем чи іншими метале- вими гострими інструментами. До механічного способу належить і кип'ятіння кераміки у воді або нагрівання в термошафі до температур $+100 \ldots+150^{\circ} \mathrm{C}$. Такий метод небезпечний для погано обпаленого, сильно пористого черепка або ж для пошкодженої глазурі і зовсім непридатний для незакріплених ангобів. Кип'ятіння у воді - це крайній метод. Його можна застосовувати тільки до міцного товстостінного фаянсу, фарфору і лише тоді, коли виріб цілий, без наскрізних тріщин. Тонкостінні керамічні фрагменти можуть деформуватись, і склеювання їх буде ускладнене.

Мити порцеляну, фаянс можна тільки м'якою щіткою в теплій воді з додаванням спирту. Таким способом можна мити тільки предмети без тріщин і з непошкодженою глазур'ю.

Хімічний спосіб - тут вибір розчинної речовини залежить як від природи забруднення, так і від правильного розуміння хімічних процесів, що відбуваються у цей момент на поверхні чи всередині черепка.

Кераміка - пористий матеріал з великою внутрішньою площею. На поверхні пор знаходяться функціональні групи силікатів, які здатні взаємодіяти з речовиною в розчинах та можуть проникати всередину кераміки. Кількість таких груп визначається природою глин. Кераміка, перебуваючи в грунті, витягує позитивно заряджені катіони металів з грунтових розчинів, подібний процес відбувається під час реставрації. Тому найнейтральніший розчин - вода - теж повинна бути хімічно чистою, тобто дистильованою, оскільки у звичайній воді катіони кальцію, магнію і заліза міцно зв’язуються з іонами на поверхні пор і, таким чином, притягується ще більша кількість води. Пори, наповнюючись водою, можуть дати поштовх руйнівному процесові.

\section{Технологія та опис процесів реставрації.}

1. Демонтаж - розклеювання, видалення доповнень, сполучних матеріалів, кріплень (вказують спосіб, розчинники для демонтажу).

2. Очищення поверхні предмета, поверхні зламів фрагментів, місць кріплення (вказують спосіб, склад розчинів).

3. Видалення солей (вказують спосіб).

4. Обробка поверхні з біопошкодженнями - біозахист, декатамінація, дезінфекція, 
стерилізація (вказують склад розчинів, спосіб обробки).

5. Розчищення від слідів попередніх реставрацій - клейових швів, місць доповнень, записів (вказують спосіб, склад розчинників).

6. Укріплення черепка (вказують склад розчину, технологію).

7. Склеювання (вказують клей, марку).

8. Доповнення втрачених фрагментів (вказують матеріал та спосіб).

9. Мастикування відколів, швів склеювань (вказують склад мастик).

10. Обробка поверхні доповнень інструментами, абразивами (вказують інструмент, матеріал, марку абразивів).

11. Знебарвлення (вибілювання) швів склеювання, місць доповнення, записів (вказують склад розчинів, способи вибілювання).

12. Імітація розпису поверхні доповнення, мастикованої поверхні (вказують матеріал, фарби, маркування, спосіб нанесення).

13. Імітація глазурі - покриття консерваційним лаком поверхні доповнень, мастикованих поверхонь, потертостей (вказують матеріал, марку, лак, спосіб нанесення).

Доповнення втрачених фрагментів і нанесення декоративно-захисних покриттів $€$ завершальним етапом реставраційних робіт. На практиці такий метод називають тонуванням поверхні доповнень.

Сучасні реставраційні матеріали дають змогу імітувати різноманітні керамічні вироби, колір черепка, глазурі, фактурні відмінності поверхні, а також різні художні прийоми декорування: пензлевий розпис, деколь, елементи орнаменту, друк, штампи, позолоту. Але слід звертати увагу на те, що можливість допустимості імітації обмежується загальними методологічними принципами. Так, наприклад, під час реставрації унікальної, археологічної чи стародавньої кераміки доповнення втрат або зовсім не тонуються, щоб підкреслити збережену частину оригіналу, або тонування виконують, використовуючи низку декоративних прийомів, що уможливлюють легке розрізнення реставраційних доповнень. Серед таких прийомів декорування можна назвати висвітлення тонувань порівняно із загальним тоном предмета, нанесення фарби і лаку таким способом, при якому утворюється відмінність фактури відновленої поверхні від оригіналу. Якщо, наприклад, керамічний виріб вкритий глазур'ю і має блискучу поверхню, то у процесі доповнення втрати фрагменти слід виконати в тон черепка, але не імітувати глянець.

Методологічною основою вибору способів доповнення втрат $є$ поділ керамічних виробів на ціннісні категорії:

Перша категорія: унікальна кераміка - археологічні пам'ятки та вироби, виготовлені до XVIII ст. Це переважно груба кераміка (гончарний товар, теракота, майоліка), а також тонкий (фаянс, східний фарфор).

Друга категорія: авторські та малосерійні твори XVIII-XX ст. Це вироби центрів керамічного виробництва (мануфактур, заводів, майстерень) у всіх керамічних матеріалах.

Третя категорія: серійні твори XIX-XX ст. ручного декорування. Це архітектурно-декоративні вироби, кустарна й народно-побутова пластика, етнографічна кераміка.

Четверта категорія: масова тиражована кераміка XIX-XX ст. Це побутова, архітектурнодекоративна кераміка й мала пластика (посуд, вази, підсвічники, статуетки).

Для першої ціннісної групи кераміки виключається відтворення елементів декору (пензлевого розпису, орнаменту тощо) (Реставрация музейной керамики: Метод. рек.).

Для кераміки другої і третьої ціннісних категорій допускається більш повна імітація кольору і декору, але за безумовного використання прямих аналогій. Однак, якщо обсяг доповнюваних втрат значний, а техніка відтворення малюнка розпису досить складна, то бажано відмовитися від повної імітації. Водночас можливе відновлення незначних елементів розпису на ділянках, прилеглих до оригінальних, де чітко простежується продовження ліній малюнка або зустрічаються повторювані елементи розпису, які можна копіювати. В іншому разі краще обмежитися наближеною імітацією, використовуючи прийоми нейтралізації привнесених доробок. До таких прийомів можна віднести пом'якшення колірної контрастності, відтворення малюнка розмитими тонами, доповнення ручного розпису технікою пуантелі, трафарету, ретуші, нанесення фарби аерографом. 
Матеріали, що застосовуються під час виконання тонувань і їхньої консервації, мають забезпечувати можливість профілактичного догляду за експонатом в умовах музейного зберігання, тобто бути стійкими до засобів профілактичної обробки. Зауважимо, що від правильного вибору матеріалів та методів декорування доповнень залежить успіх всієї реставраційної роботи над пам'яткою, тому такі операції вимагають від виконавця особливо коректного вирішення цього завдання. Важливими умовами щодо проведення наукової реставрації керамічних виробів є загальні методичні вимоги, до яких належать: максимальна збереженість пам'ятки, відмінність привнесених доповнень, оборотність реставраційних матеріалів, обмеженість реставраційних втручань.

Умови зберігання музейних предметів з кераміки передбачають наступне:

- невеликі за розміром предмети з кераміки, фарфору та інших подібних матеріалів (зокрема й скульптури) зберігаються на полицях у засклених шафах. Необхідно стежити за правильним розташуванням предметів, враховуючи їхній тиск на полицю;

- полиці для розміщення дрібних предметів повинні бути переважно дерев'яними;

- під час розміщення високі предмети необхідно ставити впритул до стіни, а невеликі - попереду, так, щоб вони не торкалися одне одного;

- керамічні, фаянсові та порцелянові тарілки потрібно зберігати вертикально у спеціальних дерев'яних «гребінках»;

- при зберіганні порцелянових і фаянсових тарілок стопками в кожній стопці не повинно бути більше 6 штук, якщо ж їхня вага досить велика, то кількість предметів у стопці необхідно зменшити. Важчі предмети треба розташовувати знизу;

- при зберіганні тарілок у стопках, щоб уникнути пошкодження глазурі або розпису, їх необхідно перекладати м'яким матеріалом (пухирчаста плівка, тонкий папір у декілька шарів, байка, фланель);

- керамічні, а також скляні предмети слід зберігати окремо, не змішуючи їх з іншими видами матеріалів;

- заборонено розміщувати серед предметів кераміки і скла будь-які інші предмети;
- предмети під час розташування слід групувати за певними ознаками (за країною, часом виготовлення, заводом тощо);

- великі предмети з неглазурованої порцеляни (бісквіту) і кераміки повинні зберігатися під ковпаками або під чохлами з щільної тканини на стелажах або підставках;

- пористу й неглазуровану кераміку потрібно особливо ретельно оберігати від пилу і вологи;

- при перенесенні, установці, розміщенні виробів з фарфору, фаянсу, скла необхідно дотримуватися великої обережності.

\section{$\square$ Реставрація текстилю.}

Предмети з органічних матеріалів (таких як текстиль, шкіра, дерево тощо) мають схильність до сильних руйнувань. Виділяються різні види текстилю:

- виготовлені повністю з одного матеріалу;

- виготовлені з волокон рослинного і тваринного походження (у стародавніх курганах часто зустрічаються знахідки тканин з вовняною ниткою основи і лляним утоком);

- із застосуванням металізованих ниток.

Текстиль з волокон тваринного походження і рослинних волокон схильний до різних видів руйнувань. Льон, коноплі та інші рослинні волокна руйнуються швидко, особливо в грунті. Тому під час археологічних розкопок їх знаходять дуже рідко. Руйнування вовни і шовку, а також шкіри відбувається під впливом навколишнього середовища, мікроорганізмів, грибів тощо. Відбувається старіння, втрачається пластичність, вицвітають барвники тканини. Залежно від умов тривалого перебування, тканини можуть бути дуже сухими, такими, що втратили пластичність, або ж вологими - з вологого шару грунту. У першому випадку тканина може кришитися, в іншому - розсипатися в руках. Зустрічаються такі види текстильних залишків, як:

- фрагменти, що повністю або частково зберегли форму виробу і структуру волокон;

- спресовані з грунтом залишки;

- мінералізовані відбитки на предметах, що зберегли характер переплетення текстилю.

Методи, що застосовуються під час реставрації текстилю, повинні бути максимально оборотними. За необхідності має бути можливість відокремити дублюючі матеріали від оригіналу. 
Необхідно зберігати фізичні властивості текстилю та відновлювати їх, якщо вони втрачені. Процес реставрації текстилю передбачає наступні етаnu:

- вивчення стану збереженості предмета;

- первинну обробку та очищення;

- визначення методики та послідовність етапів реставраціі;

- дублювання (наклеювання на нову основу);

- реконструкцію, що може включати доповнення втрачених частин.

До реставраційних заходів також входить:

- відновлення гігроскопічності, еластичності, міцності текстилю;

- нанесення захисного шару, що ізолює тканину від контакту з навколишнім середовищем;

- очищення від поверхневих і внутрішніх забруднень;

- відновлення цілісності виробу;

- наклеювання на нову основу.

Для запобігання розвитку мікроорганізмів, цвілевих грибів предмети з текстилю піддають антисептуванню. У процесі реставрації тканину піддають очищенню і пластифікації.

Пластифікація - це процес насичення тканин нелеткими низькомолекулярними речовинами (пластифікаторами), що підвищують їхню пластичність й (або) еластичність. Фрагменти текстилю, що збереглися на металевих предметах, просочують зміцнювальним розчином. Для цього застосовуються розчини та клеї, що утворюють поверхневу плівку. Зміцнювання волокна, утворення захисної плівки та проклеювання можна виконувати одночасно або окремо, в залежно від якості тканин (Степанова).

У реставрації текстильних виробів застосовують універсальні речовини (клейстер), які виконують відразу кілька функцій: укріплення структури волокна; утворення захисного поверхневого шару; приклеювання тканини до нової основи.

Основні принципи дослідження й опису музейних тканин полягають у визначенні:

- природи волокна (волокнистого складу) тканини;

- способу виробництва, (виду) обробки тканини;
- структури, способу виробництва та характеру обробки ниток;

- виду ткацького переплетення;

- щільності тканини по основі й утоку;

- орнаментації колірної гами;

- ширини тканини (в низці випадків така ознака поряд з характером обробки крайки є важливим технологічним показником).

Структура опису музейних тканин. Морфологічні параметри тканин:

- кількість предметів;

- визначення форми;

- конструктивні особливості (кількість складових частин);

- визначення розміру (довжина, ширина).

\section{Матеріально-технологічні параметри тка-} нин:

- природа волокна, спосіб виготовлення ниток (ручний, машинний);

- структура ниток (одиночна, трощена, кручена);

- напрямок скручування ниток (зліва / справа);

- спосіб виробництва тканини (ручний, машинний);

- вид ткацького переплетення;

- спосіб закладення кромки;

- щільність тканини (за основою / утоком);

- характер обробки пряжі;

- остаточна обробка нитки / тканини.

Декоративні характеристики тканин:

- спосіб декорування (створення візерунка в процесі ткання та / або поверхневе декорування);

- орнаментація та колірне вирішення (основні кольори);

- барвники (природні, штучні);

- фактура матеріалу;

- визначення рапорту візерунка та рапорту кольору (за основою / утоком).

Як видно з наведеної структури, всю інформацію про пам'ятку розділено на три блоки. Перший містить морфологічні параметри опису тканин, другий - ознаки, що характеризують матеріально-технологічні параметри опису тканин, третій - декоративні характеристики тканин.

Найприйнятнішим методом дослідження музейних текстильних виробів $є$ органолеп- 
тичний. Він базується на використанні органів чуття людини і може застосовуватись для визначення на око або на дотик природи волокна, особливостей структури і будови поверхні тканини, визначення орнаментації та ії̈ колористики (за винятком проб на горіння і розбирання тканини на окремі нитки). Водночас бажаною умовою застосування цього методу є наявність у дослідника достатнього досвіду і навичок у визначенні окремих характеристик тканин за зовнішніми ознаками.

3 огляду на суттєві відмінності в органах чуттів у різних людей органолептичний метод дослідження є певною мірою суб'єктивним, але водночас і єдиним та найприйнятнішим методом дослідження тканин у музейних умовах (оскільки не вимагає спеціального обладнання і великих витрат часу).

Таким чином, головне завдання цієї методики полягає в тому, щоб найбільш доступно донести до дослідника, що має невеликий досвід роботи з текстильними виробами, найважливіші положення у визначенні основних характеристик тканин.

Умови зберігання музейних предметів з тканин:

- тканини зберігають окремо за матеріалами (шовк, вовна, бавовняна тканина) в глухих шафах, гардеробах, комодах, скринях і скриньках;

- одяг з перлами і дорогоцінними каменями зберігається у чохлах, щоб уникнути осипання прикрас;

- предмети з хутра зберігають у приміщеннях чи спеціальних боксах зі зниженою температурою;

- шафи для зберігання текстильних виробів мають складатися з декількох висувних ящиків-лотків різних розмірів для зберігання великих і дрібних предметів;

- забороняється оббивати сукном вітрини, комоди, шафи та ящики, в яких зберігаються тканини. Слід застосовувати хімічно нейтральні матеріали;

- заборонено згинати тканини, оскільки в місцях згинів, особливо шовкової тканини, вона січеться;

- фрагменти тканин, вишивок або мережива мають бути розкладені горизонтально на по- лицях, лотках або в коробках, за можливості слід уникати перегинів. У разі, якщо розмір текстильного виробу не дозволяє зберігати його в розгорнутому вигляді, його необхідно накрутити у вигляді рулону або скласти, використовуючи об'ємні прокладки у місці складок для уникнення заломів ниток;

- кожен предмет перекладають мікалентним або цигарковим папером, чи білою чистою бавовняною тканиною;

- зберігати одяг слід переважно у горизонтальному положенні в максимально розправленому вигляді. У разі, коли костюми зберігаються на плічках, форма останніх повинна відповідати кроєві одягу і мати м'які накладки. Кожен костюм, навіть якщо він зберігається у шафі, повинен бути додатково ізольований: поміщений в чохол з паперу, бавовняної тканини чи нетканого матеріалу. Чохол повинен мати маркування з інформацією про об'єкт, що в ньому зберігається;

- головні убори зберігаються на індивідуальних болванках у футлярах або коробках з безкислотного картону. Якщо ж спеціальних болванок немає, то кожен головний убір заповнюється мікалентним папером, щоб не спотворилася його форма, і також вкладається у футляр або коробку;

- шафи, ящики, коробки з костюмами, головними уборами, зразками тканин, мережива, вишивки слід перевіряти на наявність личинок комах не менше двох разів на рік, розкладати і замінювати репеленти;

- шпалери й килими зберігають накрученими на вал діаметром не меншим 15 см лицьовою стороною назовні. Вал повинен мати по торцях кружала для опори при зберіганні в лежачому положенні. Діаметр кружала валу повинен на 5 см перевищувати діаметр накатаного на вал килима або шпалери;

- якщо вали з килимами розмішують на кронштейнах, то вал робиться без кружала, а його довжина має бути на 20 см більшою за ширину килима;

- не рекомендується накатувати декілька шпалер на один вал;

- після накатування вал з засуканими на нього килимом чи шпалерами ретельно обгортають цупким папером або бавовняною тканиною 
та перев’язують широкою смугою тканини. При накатуванні шпалери і килима на вал необхідно уникати утворення складок;

- усі шари килима при накручуванні на вал мають бути перекладені мікалентним папером. Поруч з експонатами розміщують подушечки чи саше, просочені екологічно безпечним фумігаційним складом;

- поверх килима на вал накочується паперовий або бавовняний чохол чи обгортка;

- всі матеріали мають бути екологічно чистими, нові пакувальні тканини перед використанням необхідно випрати від фабричного апрету;

- якщо немає можливості зберігати килими і шпалери на валах, їх необхідно періодично перекладати, переміщуючи складки згинів;

- прапори зберігаються намотаними на древко та затягнутими в чохли. Виняток становлять прапори, зображення і написи на яких виконані фарбами, а також прапори з рельєфною вишивкою. Такі прапори зберігають розгорнутими на горизонтальних полицях;

- предмети із золотим, срібним, перлинним та іншим рельєфним шитвом, а також з хутряними прикрасами рекомендують зберігати окремо, перекладаючи кожен предмет папером і розташовуючи між ними прокладку з байки або декількох шарів мікалентного паперу. Обгортання папером оберігає від потемніння срібні прикраси і шитво;

- якщо немає можливості зберігати великого розміру шиті предмети в горизонтальному положенні, їх можна намотати на вали діаметром не менше 20 см. Таке намотування здійснюють лицьовою стороною вгору і прокладають мікалентним папером;

- тендітні тканини, зокрема археологічні, слід зберігати горизонтально, в спеціальних папках чи бокс-коробках. Зберігати, як і переміщати, тендітні тканини слід на твердій основі на планшетах з безкислотного картону 3 м'якою щільною підкладкою, обтягнутою неслизькою тканиною. Тонку тканину роз- міщують на планшеті й щільно покривають мікалентним папером, фіксуючи їі по периметру;

- необхідно систематично провітрювати, чистити і протирати шафи, комоди і ящики, де зберігаються тканини;

- обезпилювання тканин здійснюється наступним чином: килими, гобелени, шпалери, одяг з грубого сукна очищують пилососами, що мають щітки з довгим ворсом, або м'якими одежними щітками, при цьому необхідно контролювати потужність всмоктування пилососа і застосовувати страхувальну сітку, натягнуту на рамку або п’яльця;

- головні убори без прикрас обезпилюють м'якими одежними щітками;

- зразки тканин і віяла обезпилюють за допомогою легкого струшування в розгорнутому вигляді;

- тканини, прикрашені золотим шиттям, перлами і камінням, очищують м'яким флейцом з одночасним використанням пилососа. Отвір шланга повинен розміщуватися на відстані 3-5 см від поверхні ділянок, що знепилюються, і має бути перекритий сіткою;

- старі та археологічні тканини для очищення розкладають у розгорнутому вигляді на горизонтальній площині. Поверх них накладають плоску рамку, обтягнуту дрібнокомірковим сітчастим матеріалом так, щоб сітка безпосередньо прилягала до поверхні тканин, що знепилюються. Після цього проводять обробку пилососом (щіткою з довгим, м’яким ворсом, без натискування).

Висновки. Підготовка майбутніх художників-реставраторів у системі вищої професійної освіти має здійснюватися з урахуванням сучасних вимог консервації-реставрації. Узагальнення таких вимог, з акцентом на практичну діяльність та супровідні дослідження творів декоративно-ужиткового мистецтва, сприятиме набуттю професійного досвіду, формуванню професійних компетентностей і відповідального ставлення до пам'яток історії та культури.

\section{Цитовані праці}

Бобров, Юрій. Теорія реставрації пам'яток мистецтва: закономірності та протиріччя. СПб., 1997. Друк.

Зайцева, Вікторія. «Роль наукової реставрації в справі експертизи та атрибуції творів образотвор- 
чого мистецтва». Сучасні проблеми мистецтвознавчої експертної оцінки культурних иінностей та предметів колекціонування: Тези доп. Всеукр. наук.-практ. конф. (26-27 листоп. 2009 р.): Київ: ДАКККіМ, 2009. Друк.

Коваленко, Тетяна. Про підготовку реставраційних кадрів з кераміки і скла на базі ННДРЦУ Тези доп. Міжнар. наук.-практ. конф. Реставрація музейних пам'яток в сучасних умовах. Проблеми та шляхи їх вирішення: (27-29 трав. 1998 р.). Київ: ННДРЦУ, 1998. С. 61-62. Друк.

Мінжулін, Олександр. Реставрація творів з металу. Київ: Спалах, 1998. Друк.

Мінжулін, О., Мінжуліна, Т., Чорнокапська, І. Реставрація тканин. К., 1998. Друк.

Мінжуліна, Тетяна. Дослідження й реставрація музейного текстилю. К.: Рада, 2005. Друк.

Реставрация музейной керамики: Метод. рек. Ред. Л. Андреева, А. Антонян, Т. Барабанова и др. Москва, 1999. Печать.

Степанова, Юлия. Основы реставрации: Учеб. пособие. Тверь, 2018. Печать.

Тимченко, Тетяна. «Проблеми реставраційної освіти в Україні». Музеї та реставрація у контексті збереження культурної спадщини: актуальні виклики сучасності: Зб. наук. пр. V міжнар. наук.практ. конф. Київ: Фенікс, 2020. Друк.

Шемаханская, Марина. Реставрация металла: Метод. рек. Москва: ВНИИР. 1989. Печать.

\section{References}

Bobrov, Yurii. Teoriia restavratsii pamiatok mystetstva: zakonomirnosti ta protyrichchia. SPb., 1997. Druk.

Zaitseva, Viktoriia. "Rol naukovoi restavratsii v spravi ekspertyzy ta atrybutsii tvoriv obrazotvorchoho mystetstva». Suchasni problemy mystetstvoznavchoi ekspertnoi otsinky kulturnykh tsinnostei ta predmetiv kolektsionuvannia: Tezy dop. Vseukr. nauk.-prakt. konf. (26-27 lystop. 2009 r.): Kyiv: DAKKKiM, 2009. Druk.

Kovalenko, Tetiana. Pro pidhotovku restavratsiinykh kadriv z keramiky i skla na bazi NNDRTsU Tezy dop. Mizhnar. nauk.-prakt. konf. Restavratsiia muzeinykh pamiatok v suchasnykh umovakh. Problemy ta shliakhy yikh vyrishennia: (27-29 trav. 1998 r.). Kyiv: NNDRTsU, 1998. S. 61-62. Druk.

Minzhulin, Oleksandr. Restavratsiia tvoriv z metalu. Kyiv: Spalakh, 1998. Druk.

Minzhulin, O., Minzhulina, T., Chornokapska, I. Restavratsiia tkanyn. K., 1998. Druk.

Minzhulina, Tetiana. Doslidzhennia y restavratsiia muzeinoho tekstyliu. K.: Rada, 2005. Druk.

Restavracziya muzejnoj keramiki: Metod. rek. Red. L. Andreeva, A. Antonyan, T. Barabanova i dr. Moskva, 1999. Pechat'.

Stepanova, Yuliya. Osnovy' restavraczii: Ucheb. posobie. Tver', 2018. Pechat'.

Tymchenko, Tetiana. «Problemy restavratsiinoi osvity v Ukraini». Muzei ta restavratsiia u konteksti zberezhennia kulturnoi spadshchyny: aktualni vyklyky suchasnosti: Zb. nauk. pr. V mizhnar. nauk.-prakt. konf. Kyiv: Feniks, 2020. Druk.

Shemakhanskaya, Marina. Restavracziya metalla: Metod. rek. Moskva: VNIIR. 1989. Pechat'.

Подано до редакції 21.09.2021

\section{Рецензенти:}

Школьна О. В. - доктор мистецтвознавства, професор;

Тимченко Т. Р. - кандидат мистецтвознавства, доцент. 